\title{
Rising trends of HCV infection over a period of 4 years among blood donors in central India: A retrospective study
}

$\overline{1}$
0
0
0
0
0
0

\section{Alok Kumar, Satish Sharma, Narayan Ingole, Nitin Gangane}

Department of Pathology, Mahatma Gandhi Institute of Medical Sciences, Sewagram, Wardha, Maharashtra, India.

Address for Correspondence: Dr. Alok Kumar, J.N.B.H, MGIMS, Sewagram, Wardha - 442 102, Maharashtra, India. E-mail: alokkryahoo.com Ikr@ gmail.com

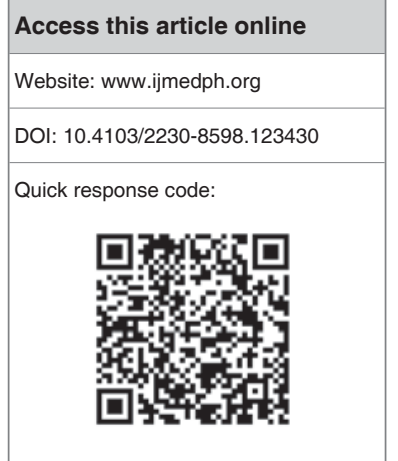

Objective: The aim of the study was to find out the sero-prevalence of Hepatitis C infection among blood donors. Materials and Methods: All collected blood bags were screened for anti-hepatitis $\mathrm{C}$ virus antibodies (HCV Ab; MicroELISA 3rd generation, J. Mitra) during the study period of 4 years and data were analyzed. Results: A total of 28621 blood donors were screened for transfusion transmissible infections (TTIs) in which 80 donors were positive for Hepatitis C infection, constituted $11 \%$ of total sero-reactive donors. In 2009, only 10 cases were sero-reactive while in 2012, 36 cases were sero-reactive for Hepatitis C infection. Conclusions: Hepatitis C infection among blood donors are in rising trends in this study area. Voluntary donors are safer than replacement donors as they have very low sero-prevalence. As these blood donors represent the highly selective community of a general population in most of the countries. So the actual sero-prevalence of hepatitis $C$ infection may be more in the general population. Promoting HCV screening, voluntary blood donation, diagnosis and treatment among blood donors are very important measures to control the transmission of HCV infection, decrease sero-reactive cases and ensure safe blood collection.

Key words: Blood donors, hepatitis C infection, sero-prevalence

\section{INTRODUCTION}

HCV is recognized as the primary cause of transfusion-associated non-A-non-B viral hepatitis worldwide, ${ }^{[1]}$ and is endemic in West Africa. ${ }^{[2]}$ Hepatitis $C$ virus (HCV) cause serious mortality, morbidity and financial burden, thus are major global health problem..$^{[3]}$ The actual prevalence of HCV is difficult to assess because serological tests do not discriminate among acute, chronic, or resolved infection and the analyzed groups in most countries are not representative of the general population. ${ }^{[4]}$

However; most studies use blood donors as prevalence to report the frequency of HCV usually by anti-HCV antibodies and do not report follow-up HCV testing. Using blood donors as a prevalence source may underestimate the actual prevalence of the virus because donors are generally a highly selected population. ${ }^{[5]}$ The aim of this study, was to find out the sero-reactive cases of Hepatitis C infection among blood donors during 4 years in central india.

\section{MATERIALS AND METHODS}

The study was carried out in the Blood bank attached to a tertiary care hospital, Central India over a period of 4 years from January 2008 to December 2012. It was a retrospective study. All blood donations collected during this period were included. The donors were either voluntary or replacement donors. Replacement donors were either relatives or friends of patients.

All blood bags were screened for hepatitis B surface antigen (HBsAg; Hepalisa, J. Mitra), anti-human immunodeficiency virus antibodies (HIV Ab; HIV 3rd generation kit for detection of antibodies to HIV1 and HIV2, J. Mitra), anti-hepatitis C virus antibodies (HCV Ab; MicroELISA 3rd generation, J. Mitra) and Venereal Diseases Research Laboratory (VDRL) reactivity (Carbogen kit, Tulip Diagnostics). The data were analyzed with respect to sero-reactive cases. 


\section{RESULTS}

A total of 28621 blood donors were screened for transfusion transmissible infections (TTIs) during the study period in which voluntary donors were 23133 while the replacement donors were 5488 as shown in [Table 1].

A total of 728 blood donors were found positive for transfusion transmitted infections (TTIs) during the study period in which Hepatits B was the most common infection followed by HIV and then, Hepatitis $\mathrm{C}$ infection. There is gradual rise in HCV infection per year as shown in [Table 2].

Rising trends of $\mathrm{HCV}$ infection among blood donors and seroprevalence of Hepatitis $\mathrm{C}$ infection was shown in [Table 3].

Using Chi-Square Value, significant association was found between blood donors and $\mathrm{HCV}$ infection in four years duration.

Distribution of HCV infection among replacement donors as well as voluntary donors was shown in [Table 4].

\section{DISCUSSION}

With every unit of blood, there is $1 \%$ chance of transfusion associated problems including TTI. ${ }^{[6]}$ The risk of TTI has declined dramatically

\begin{tabular}{|c|c|c|c|c|}
\hline Duration & $\begin{array}{l}\text { Voluntary } \\
\text { Donors in } \\
\text { blood bank }\end{array}$ & $\begin{array}{l}\text { Replacement } \\
\text { Donors }\end{array}$ & $\begin{array}{c}\text { Voluntary } \\
\text { donors in } \\
\text { Camp }\end{array}$ & $\begin{array}{c}\text { Total } \\
\text { Donors }\end{array}$ \\
\hline 2009 & 2974 & 1336 & 1102 & 5412 \\
\hline 2010 & 3900 & 1617 & 1248 & 6765 \\
\hline 2011 & 5420 & 1247 & 1468 & 8135 \\
\hline 2012 & 5542 & 1288 & 1479 & 8309 \\
\hline Total & 17836 & 5488 & 5297 & 28621 \\
\hline
\end{tabular}

\begin{tabular}{|c|c|c|c|c|c|}
\hline Duration & HBs Ag & HIV & $\mathrm{HCV}$ & VDRL & Total TTIs \\
\hline 2009 & 113 & 34 & 10 & 09 & 166 \\
\hline 2010 & 112 & 34 & 15 & 05 & 166 \\
\hline 2011 & 106 & 39 & 19 & 09 & 173 \\
\hline 2012 & 152 & 28 & 36 & 07 & 223 \\
\hline Total & 483 & 135 & 80 & 30 & 728 \\
\hline
\end{tabular}

\begin{tabular}{lcccc}
\multicolumn{5}{l}{ Table 3: Sero-reactivity of HCV infection yearwise } \\
\hline Year & $\begin{array}{c}\text { Sero-reactive } \\
\text { cases of HCV } \\
\text { infection }\end{array}$ & $\begin{array}{c}\text { Total blood } \\
\text { donors }\end{array}$ & $\begin{array}{c}\text { Chi - } \\
\text { Square } \\
\text { Value }\end{array}$ & P-value \\
\hline 2009 & 10 & 5412 & 10.15 & 0.0173 \\
2010 & 15 & 6765 & & \\
2011 & 19 & 8135 & & \\
2012 & 36 & 8309 & & \\
Total & 80 & 28621 & & \\
\hline
\end{tabular}

\begin{tabular}{lccc}
\multicolumn{4}{l}{ Table 4: Sero-reactivity of HCV infection among } \\
voluntary and replacement donors yearwise
\end{tabular}

in high income nations over the past two decades, primarily because of extraordinary success in preventing HIV and other established transfusion transmitted viruses from entering the blood supply..$^{[7]}$

Many studies including studies done by Rao and Annapurna et al., ${ }^{[8]}$ in Pune, Rose et al., ${ }^{\left[{ }^{[0]}\right.}$ in Vellor, Arora et al., ${ }^{[6]}$ in Southern Haryana, Singh et al.,,$^{[10]}$ in Coastal Karnataka, Pahuja et al., ${ }^{[11]}$ in Delhi and Singh et al., .12] $^{[2]}$ showed that more than $90 \%$ were male donors as also in our study.

Among the studies done, Garg et al., ${ }^{[13]}$ have reported an HCV prevalence of $0.28 \%$ in blood donors of Western India. Similar studies by Sri Krishna et al. , $^{[14]}$ have noted a prevalence of $1.02 \%$, Sood et al., and Pahuja et al., have reported a high prevalence of 2.2 and $2.23 \%$ in Delhi, respectively. ${ }^{[11]}$ Added to this, HCV prevalence by Kaur et al., ${ }^{[15]}$ was $0.78 \%$, Singh et al., was $0.5 \%$ and Jain et al., it was $1.57 \%$ in New Delhi voluntary blood donors. ${ }^{[11]}$ Internationally, various studies ${ }^{[11]}$ have reported an HCV prevalence range of $0.42-1.2 \%$.

The studies ${ }^{[10-12]}$ have showed high sero-positivity rate in replacement donors compared to voluntary donors, a similar findings was noted in our study. Chandra et al., ${ }^{[16]}$ have found almost negligible infectivity rate in voluntary donors and also no voluntary donors was found to be positive for HIV by Arora et al. ${ }^{[6]}$

Among male blood donors in Karachi, Pakistan, the sero-prevalence of $\mathrm{HCV}$ was $1.8 \%$ with a trend of increasing proportion of positive donors from 1998-2002. ${ }^{[17]}$ Then 26.6\% among 188 blood donors and $22 \%$ among 163 donors were positive with both studies done in Cairo. ${ }^{[18,19]}$ Rates were lower in Saudi Arabia (1.8\%) and Yemen $(2.1 \%) \cdot{ }^{[20,21]}$ In China, prevalence rates were generally low with rates around $1 \%$ among donors in Beijing and Wuhan. ${ }^{[22,23]}$

Mathai et al., ${ }^{[24]}$ (1994-96) Trivandrum, Kerala observed that most common infection was Hepatitis C infection (1.4\%) followed by Hepatitis B infection (1.3\%) and both HIV and syphilis each were seen in $0.2 \%$ of donors.

Shrestha et al., ${ }^{[25]}$ (2004-2007), Nepal, observed that Hepatitis C infection $(0.64 \%)$ was most common infection followed by Hepatitis $\mathrm{B}(0.64 \%)$, syphilis $(0.48 \%)$ and HIV $0.12 \%$ of total donors.

Chandra et al., ${ }^{[16]}$ (2001-2006) Lucknow, U.P. observed that Hepatitis B infection was most common $(1.96 \%)$ followed by Hepatitis C infection $(0.85 \%)$, HIV $(0.23 \%)$ and syphilis was $0.01 \%$. 
Bhawani et al., ${ }^{[26]}$ (2004-2009) observed that Hepatitis B (1.41\%) was most common infection followed by Hepatitis C infection $(0.84 \%)$, $\operatorname{HIV}(0.39 \%)$ and syphilis was $0.08 \%$.

Gao et al., ${ }^{[27]}$ showed that HCV infection rate in paid blood donors was significantly higher than in voluntary blood donors $(15.53 \%$ vs $0.97 \%$ ). It was observed that no significant difference was found in HCV infection rates between male and female blood donors and the prevalence of $\mathrm{HCV}$ infection was found to increase with age.

In a study, done by Pallavi et al., ${ }^{[28]}$ found that the incidence of Hepatitis C infection is more on replacement donors $(0.23 \%)$ than volumtary donors $(0.20 \%)$

Many studies were done in different parts of India regarding seroprevalence of Hepatitis $C$ infection and when compared with our study, it was found that the sero-prevalence was low but it was in rising trends as shown in [Table 5].

Numerous researches have shown that paid blood donors are more likely to be infected with HCV than either employer-organized donors or true voluntary donors ${ }^{[27]}$. Those paid donors who were attracted by high compensation and chose to donate blood in illegal blood stations, also risked a greater risk of cross-contamination. The prevalence rate among plasma donors was significantly higher than among whole blood donors (33.95\% vs $7.90 \%$ ), possibly due to cross-contamination of blood collection equipment by $\mathrm{HCV}$ positive plasma donors. ${ }^{[31]}$ The elimination of paid plasma and whole blood donation could contribute to a reduction in $\mathrm{HCV}$ infection among blood donors.

In our study there were no paid donors.

\section{CONCLUSION}

Hepatitis $\mathrm{C}$ infection among blood donors are in rising trends in this study area. Voluntary donors are safer than replacement donors as they have very low sero-prevelence. As these blood donors represent the highly selective community of a general population in most of the countries, so the actual sero-prevalence of hepatitis $\mathrm{C}$ infection may be more in the general population. Promoting HCV screening, voluntary blood donation, diagnosis and treatment among blood donors are very important measures to control the transmission of HCV infection, decrease the sero-reactive cases and ensure safe blood collection.

\begin{tabular}{|c|c|}
\hline Different regions of India & Prevalence of HCV(\%) \\
\hline Ludhiana[ $^{[29]}$ & 1.09 \\
\hline Delhi ${ }^{[11]}$ & 0.66 \\
\hline Lucknow $^{[16]}$ & 0.85 \\
\hline Southern Haryana ${ }^{[6]}$ & 1.0 \\
\hline West Bengal[30] & 0.31 \\
\hline Bangalore $^{[14]}$ & 1.02 \\
\hline Present Study & 0.28 \\
\hline
\end{tabular}

\section{REFERENCES}

1. Houghton M, Weiner A, Han J, Kuo G, Choo QL. Molecular biology of the hepatitis $C$ viruses: Implications for diagnosis, development and control of viral disease. Hepatology 1991;14:381-8.

2. Jeannel D, Fretz C, Traore Y, Kohdjo N, BigotA, Pê Gamy E, et al. Evidence for high genetic diversity and long term endemicity of hepatitis $C$ virus genotypes 1 and 2 in West Africa. J Med Virol 1998;55:92-7.

3. Kleinman SH, Kuhns MC, Todd DS, Glynn SA, McNamara A, DiMarco A, et $a$ al. Frequency of HBV DNA detection in US blood donors testing positive for the presence of anti HBc: Implications for transfusion transmission and donor screening. Transfusion 2003;43:696-704.

4. Lavanchy D. The global burden of hepatitis C. Liver Int 2009;29 Suppl 1:74-81.

5. Alter MJ, Kruszon-Moran D, Nainan OV, McQuillan GM, Gao F, Moyer LA, et al. The prevalence of hepatitis $C$ virus infection in the United States, 1988 through 1994. N Engl J Med 1999;341:556-62.

6. Arora D, Arora B, Khetarpal A. Seroprevalence of HIV, HBV, HCV and syphilis in blood donors in Southern Haryana. Indian $\mathrm{J}$ Pathol Microbiol 2010;53:308-9.

7. Fiebig EW, Busch MP. Emerging infections in transfusion medicine. Clin Lab Med 2004;24:797-823.

8. Rao P, Annapurna K. HIV status of blood donors and patients admitted in KEM hospital, Pune. Indian J Hematol Blood Transfus 1994;12:174-6.

9. Dolly R, Annie S, Thaiyanayaki P, George PB, Jacob TH. Increasing prevalence of HIV antibody among blood donors monitored over 9 years in blood bank. Indian J Med Res 1998;108:42-4.

10. Singh $\mathrm{K}, \mathrm{Bhat} \mathrm{S}$, Shastry $\mathrm{S}$. Trend in seroprevalence of Hepatitis B virus infection among blood donors of coastal Karnataka, India. J Infect Dev Ctries 2009;3:376-9.

11. Pahuja S, Sharma M, Baitha B, Jain M. Prevalence and trends of markers of hepatitis $C$ virus, hepatitis $B$ virus and humany immunodeficiency virus in Delhi blood donors. A hospital based study. Jpn J Infect Dis 2007:60:389-91.

12. Singh B, Verma M, Kotru M, Verma K, Batra M. Prevalence of HIV and VDRL seropositivity in blood donors of Delhi. Indian J Med Res 2005; 122:234-6

13. Garg S, Mathur DR, Gard DK. Comparison of seropositivity of HIV, HBV, $\mathrm{HCV}$ and syphilis in replacement and voluntary blood donors in western India. Indian J Pathol Microbiol 2001;44:409-12.

14. Srikrishna A, Sitalakshmi S, Damodar P. How safe are our safe donors. Indian J Pathol Microbiol 1999;42:411-6.

15. Kaur H, Dhanoa J, Pawar G. Hepatitis C infection amongst blood donors in Punjab-A six year study. Indian J Hematol Blood Transfus 2001;19:21-2.

16. Chandra T, Kumar A, Gupta A. Prevalence of transfusion transmitted infections in blood donors: An Indian experience. Trop Doct 2009;39:152-4.

17. Aktar $\mathrm{S}$, Younus $\mathrm{M}$, Adil $\mathrm{S}$, Jafri $\mathrm{SH}$, Hassan $\mathrm{F}$. Hepatitis $\mathrm{C}$ virus infection in asymptomatic male volunteer blood donors in Karachi, Pak. J Viral Hepat 2004;11:527-35.

18. Bassily S, Hyams KC, Fouad RA, Samaan MD, Hibbs RG. A high risk of hepatitis $\mathrm{C}$ infection among Egyptian blood donors: The role of parenteral drug abuse. Am J Trop Med Hyg 1995;52:503-5.

19. Darwish MA, Raouf TA, Rushdy P, Constantine NT, Rao MR, Edelman $\mathrm{R}$, et al. Risk factors associated with a high seroprevalence of hepatitis $\mathrm{C}$ virus infection in Egyptian blood donors. Am J Trop Med Hyg 1993;49:440-7.

20. al-Faleh FZ, Ramia S, Arif M, Ayoola EA, al-Rashed RS, al-Jeffry M, et al. Profile of hepatitis $C$ virus and the possible modes of transmission of the virus in the Gizan area of Saudi Arabia: A community-based study. Ann Trop Med Parasitol 1995;89:431-7.

21. El Guneid AM, Gunaid AA, O'Neill AM, Zureikat NI, Coleman JC, MurrayLyon IM, et al. Prevalence of hepatitis B, C and D virus markers in Yemeni patients with chronic liver disease. J Med Virol 1993;40:330-3.

22. Wang $\mathrm{Y}$, Tao QM, Zhao HY, Tsuda F, Nagayama R, Miyakawa $\mathrm{Y}$, et al. Hepatitis C virus RNA and antibodies among blood donors in Beijing. J Hepatol 1994;21:634-40.

23. Zhang YY, Hansson BG, Widell A, Nordenfelt E. Hepatitis C virus antibodies and hepatitis $\mathrm{C}$ virus RNA in Chinese blood donors determined 
by ELISA, recombinant immunoblot assay and polymerase chain reaction. APMIS 1992;100:851-5.

24. Mathai J, Sulochana PV, Satyabhama S, Nair PK, Sivakumar S. Profile of transfusion transmissible infections and associated risk factors among blood donors of Kerala. Indian J Pathol Microbiol 2002;45:319-22

25. Shrestha AC, Ghimire P, Tiwari BE, Rajkarnikar M. Transfusion transmissible infections among blood donors in Kathmandu, Nepal. J Infect Dev Ctries 2009;3:794-7.

26. Bhawani Y, Rao PR, Sudhakar V. Seroprevalence of transfusion transmissible infections among blood donors in a tertiary care hospital of Andhra Pradesh. Biol Med 2010;2:45-8.

27. Gao X, Cui Q, Shi X, Su J, Peng Z, Chen X, et al. Prevalence and trend of hepatitis $C$ virus infection among blood donors in Chinese mainland: $A$ systematic review and meta-analysis. BMC Infect Dis 2011;11:88.

28. Pallavi P, Ganesh CK, Jayashree K, Manjunath GV. Seroprevalence and trends in transfusion transmitted infections among blood donors in a university hospital blood bank: A 5 year study. Indian J Hematol Blood
Transfus 2011;27:1-6

29. Gupta N, Kumar V, Kaur A. Seroprevalence of HIV, HBV, HCV and syphilis in voluntary blood donors. Indian J Med Sci 2004;58:255-7.

30. Bhattacharya P, Chakraborty S, Basu SK. Significant increase in HBV, HCV, HIV and syphilis infections among blood donors in West Bengal, Eastern India 2004-2005. Exploratory screening reveals high frequency of occult HBV infection. World J Gastroenterol 2007;13:3730-3.

31. Ji Y, Ren QH, Zhu ZY, Qu DM, Qiu ZK, Li JF, et al. Analysis of hepatitis $C$ virus infection among blood donors in China. J Chin Acad Med Sci 1998;20:240-1.

How to cite this article: Kumar A, Sharma S, Ingole N, Gangane $\mathrm{N}$. Rising trends of HCV infection over a period of 4 years among blood donors in central India: A retrospective study. Int $\mathrm{J}$ Med Public Health 2013;3:240-3.

Source of Support: Nil. Conflict of Interest: No conflict of Interest. 